\title{
Above ground biomass and leaf area models based on a non destructive method for urban trees of two communes in Central Chile
}

\author{
Ecuaciones de biomasa aérea y área foliar basadas en métodos no destructivos para \\ árboles urbanos de dos comunas de Chile Central
}

\section{Cynnamon Dobbs ${ }^{a}$, Jaime Hernández ${ }^{\text {b*, }}$ Francisco Escobedo ${ }^{c}$}

${ }^{a}$ University of Melbourne, Australian Research Centre for Urban Ecology, Melbourne, Australia.

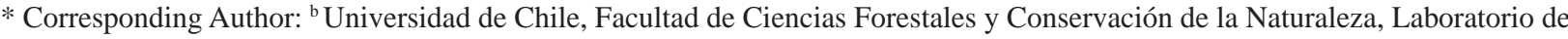 \\ Geomática y Ecología del Paisaje (GEP), Santiago, Chile, casilla 9206, tel.: 56-02-9785873, jhernand@uchile.cl \\ ${ }^{c}$ University of Florida - IFAS School of Forest Resouerces and Conservation, Gainesville, FL, USA.
}

\begin{abstract}
SUMMARY
Biomass is regarded as an important indicator of ecological and management processes in urban vegetation, difficult to measure but easy to interpret. Existence and growing rates of biomass can be used to calculate carbon storage and sequestration, estimate dry deposition of air pollution or volatile organic compound emissions. In cities, management practices also affect the amount and distribution of biomass components within a tree and local calibrated equations should be used. However, traditional destructive methods to gather the data necessary to build such equations are less practical in urban environments. The main objective of this work was to develop above ground biomass and leaf area models by using non destructive methods for common urban trees in Santiago, Chile. We used randomised branch sampling (RBS), a non-destructive method, and easily measured variables such as DBH and total height to estimate crown biomass and leaf area for the 11 most common urban tree species in Santiago. Results using equations developed in this study yielded crown biomass estimates, comparable and within the range of values reported in literature and within those obtained from urban forest structure models. Leaf area results yielded more reasonable estimates when compared to field data and urban forest structure models. These equations can be incorporated into urban forest function models for more precise estimates of Latin American temperate urban forest function. With increased sampling intensity the RBS sampling method could be presented as a non-destructive and repeatable method for estimating different types of urban tree crown characteristics.
\end{abstract}

Key words: non-destructive method, randomised branch sampling, allometry.

\section{RESUMEN}

La biomasa es considerada un importante indicador de los procesos ecológicos y de manejo que ocurren en la vegetación urbana. Es difícil de medir pero fácil de interpretar, pues refleja las condiciones del sitio y de los recursos edáficos, hídricos y de radiación solar disponibles en él. En las ciudades, las prácticas de manejo sobre los árboles afectan la distribución de la biomasa en su interior y es necesario usar ecuaciones calibradas localmente para poder evaluar cada componente. Sin embargo, los métodos destructivos tradicionales, que se usan para recopilar los datos necesarios en la construcción de tales modelos, son poco aplicables en ambientes urbanos. En este estudio se utilizó el muestreo aleatorio de ramas (RBS), un método probabilístico no destructivo, y variables dendrométricas de fácil medición como DAP y altura total para estimar la biomasa aérea y el área foliar de árboles urbanos más comunes en Santiago, Chile. Los resultados del estudio arrojaron estimaciones de biomasa aérea comparables, y dentro del rango de valores, a los reportados en la literatura internacional, para bosques y árboles urbanos. Las estimaciones para área foliar arrojaron valores más razonables en comparación con los datos de campo y referencias internacionales. Estas ecuaciones pueden ser incorporadas en los modelos forestales urbanos incluyendo estimaciones más precisas y ajustadas a la realidad de América Latina. Aumentando la intensidad de muestreo de método RBS se podría usar como un método no-destructivo, replicable, para estimar diferentes tipos de características en árboles urbanos.

Palabras clave: método no destructivo, muestreo aleatorio de ramas, alometría.

\section{INTRODUCTION}

A simple but efficient way to assess and monitor urban vegetation is to consider explicitly its structure and functions in a given urban landscape. Forest structure is a measure of various physical attributes of urban vegetation, such as tree species composition, number of trees, tree health, leaf area and biomass. Forest functions are determined by forest structure, including a wide range of environmental and ecosystem services such as air pollution removal and cooler air temperatures (Nowak et al. 2002 ). Consequently, forest values are an estimate of the economic worth of the various forest functions. In several countries, recent legislation and formal agreements have 
increased focus on utilising the urban forest to reduce $\mathrm{CO}_{2}$ emissions (McHale et al. 2007). To be able to calculate current carbon storage, biomass for single trees has to be calculated using equations from literature and measured tree data. Unfortunately, very often, these equations are not available or they have not been calibrated for local conditions.

To measure the structure of the urban forest the "urban forest effects" model (UFORE) has been widely used, and several management regimes have been based on its results. Unfortunately this model is built on allometric equations and urban forest functional models developed in the United States of America (De la Maza et al. 2005). In urban areas, most analyses of forest structure are based on this model, therefore they lack in direct measurements (McPherson and Simpson 2001). Also the variables that affect urban tree growth (i.e. soil, water, solar resources) are different among cities, therefore allometric relationships within those urban trees vary (McHale et al. 2009).

Crown biomass and leaf area can be estimated using allometric equations and measured tree dimension variables such as sapwood area, diameter at breast height (DBH), total height, and other crown measurements (Nowak 1996, McPherson 1998, Peper and McPherson 1998, Turner et al. 2000, McHale et al. 2009). Sapwood area has been found to be highly related with whole tree aboveground biomass and leaf area for many tree species (Turner et al. 2000). However, leaf biomass and leaf area equations in urban areas have to be developed using nondestructive methods due to liability and public values (McPherson 1998). Nowak (1996) for example estimated leaf biomass for open grown urban trees using easily measured dimensions such as DBH, total height, crown height and width, and a shading factor for each sampled species. The author found that estimates based on crown width had a smaller mean square error than estimates presented by models based on DBH. Other methods such as randomised branch sampling (RBS) use the individual tree as a population and use its branch structure to develop a sampling model (Gregoire et al. 1995). Randomised branch sampling is a non-destructive, multistage probability sampling method introduced by Jessen (1955) for the estimation of fruit quantity on orange trees. The sampling method uses a tree's branching structure to take measurements along sequential branches in a crown with considerably less effort than that needed for weighing all branches or piling and reselecting them by a randomised subsample. Foliar biomass is estimated by measuring the foliage of the sampled branches and not the entire crown (Gregoire et al. 1995). Peper and McPherson (1998) compared randomised branch sampling and other methods for estimating urban tree foliar biomass in Sacramento, California, against measured actual foliar biomass and found no significant difference.

Tree leaf area is also important for studying several physiological processes such as photosynthesis, transpira- tion, evapotranspiration, and productivity. Leaf area is often estimated using the leaf area index or the leaf green area representing the projection of one-sided leaf area in relation to surface unit area (Hardin et al. 2007). Direct methods include collection of foliage and litter fall, below-canopy light interception measurements, and other more destructive methods such as sapwood area measurements (Turner et al. 2000). The leaf area index is commonly obtained using the relationship between foliar mass and sapwood area for specific species (Turner et al. 2000). Nowak (1996) developed allometric equations for predicting leaf area for open-grown urban deciduous trees based on stem diameter and other crown parameters. Peper and McPherson (1998) listed other indirect methods including aerial imagery and gap fraction analysis and the use of video images, and found that image processing demonstrated the highest probability of accurately sampling the leaf area index.

By developing site-specific equations of crown biomass and leaf area, Latin American cities can better understand the function of their urban forest and assess the role of trees on the urban environment. As mentioned before, to have local calibrated biomass equations is crucial to have unbiassed and more precise estimations. The specific objectives of this study were: 1) to develop regression equations to predict crown biomass and leaf area for the 11 most common urban tree species in central Chile, and 2) to assess the use of the randomised branch sampling methods for estimating crown biomass (e.g. the sum of branch and leaf biomass) and leaf area for urban trees in central Chile. The study did verify results with leaf and branch biomass and leaf area equations from literature and those used in an urban forest structure model. It is expected to find significant differences between site specific biomass and leaf area equations and literature models estimations that make valuable the development of site specific models for crown biomass and leaf area.

\section{METHODS}

The 11 most common urban tree species in Santiago, Chile, were measured and sampled for leaf and branch biomass during the months of October and November of 2004. The dates were chosen because of tree phenology, to have a complete development of the leafy section. Santiago is located between $450 \mathrm{~m}$ and $900 \mathrm{~m}$ above sea level, at $32^{\circ} 55^{\prime}$ and $34^{\circ} 19^{\prime}$ South latitude, at $69^{\circ} 46^{\prime}$ and $71^{\circ} 39^{\prime}$ West longitude. Average annual precipitation is about 400 $\mathrm{mm}$ and is characterised by a temperate, semi-arid, Mediterranean climate with an average annual high temperature of $22^{\circ} \mathrm{C}$ and average annual low temperature of $7^{\circ} \mathrm{C}$. Sampled tree species included eight non native: Ailanthus altissima Mill., Robinia pseudoacacia L., Prunus cerasifera Ehrh., Acacia melanoxylon R. Br., Acacia dealbata Link., Acer negundo L., Liquidambar styraciflua L., Platanus $x$ acerifolia Muenchh., and three native ones: Schinus molle Raddi., Quillaja saponaria Molina, Maytenus boaria Mo- 
lina species of central Chile. See appendix for a general description of all species.

Samples were obtained from two municipalities where permission was granted (Lo Barnechea and La Reina), thus limiting sampling to these areas of Santiago. Sampled trees were open-grown without evidence of pruning, water stress, or mechanical damage. Ten trees per species were selected for sampling and represent the range of sizes found in Santiago. The range for height and DBH for each species is shown in table 1 . Similar sample sizes (DBH range 11-53 cm) have been used by Nowak (1996) for estimating tree biomass and leaf area. Individual tree stem diameter at breast height, $130 \mathrm{~cm}$, and at crown base was measured, as also were total height, height to crown base, and crown width along north-south and east-west axes. The greatest and smallest diameter of each branch section and the length of branch section were also measured for each sampled tree.

Randomised branch sampling (RBS). According to Gregoire et al. (1995) it is an iterative probability sampling approach which uses a path that consists of a series of branch sections ending in terminal branches (Gove et al. 2002). Following Gregoire et al. (1995) definition, a branch is defined as a complete stem system from lateral to terminal buds with a diameter inferior to $2.5 \mathrm{~cm}$. The section is defined as the part of the branch located between two consecutive nodes without differentiating stem or lateral branches. A path is given by a sequence of sections. Randomised branch sampling selects a data collection path from the base to the end of a tree or to a randomly selected terminal branch. The resulting sum of the probability of sample of the entire tree or branch is then used to estimate crown biomass or the sum of leaf and branch biomass in the individual tree crown.

In this study, two paths per tree were selected so that

Table 1. Diameter at breast height (DBH) and total height (H) ranges used for each species.

Rangos de diámetro a la altura del pecho (DBH) y altura total (H) de las especies utilizadas.

\begin{tabular}{lcc}
\hline \multirow{2}{*}{ Species } & \multicolumn{2}{c}{ Range of } \\
\cline { 2 - 3 } & $\mathrm{DBH}(\mathrm{cm})$ & $\mathrm{H}(\mathrm{m})$ \\
\hline Ailanthus altissima & $6-45$ & $5-22$ \\
Acer negundo & $7-45$ & $4-10$ \\
Acacia dealbata & $10-35$ & $3-9$ \\
Acacia melanoxylon & $12-40$ & $3-9$ \\
Prunus cerasifera & $7-42$ & $4-13$ \\
Robinia pseudoacacia & $7-60$ & $4-15$ \\
Liquidambar styraciflua & $6-30$ & $4-10$ \\
Platanus acerifolia & $20-80$ & $8.5-25$ \\
Schinus molle & $8-45$ & $2.5-9$ \\
Quillaja saponaria & $6-25$ & $3-6$ \\
Maytenus boaria & $8-21$ & $4-6$ \\
\hline
\end{tabular}

the standard error and variance could be calculated (Gregoire et al. 1995, Gove et al. 2002). Each path consisted of a randomly chosen branch from each node beginning at the base of the sampled tree (figure 1). The probability of selecting a variable needs to be highly correlated with the parameter to be estimated. Therefore the conditional probability associated with each branch was assigned based on the square diameter of the branch multiplied by its length and then divided by the sum of the squared diameter multiplied by the respective length of all branches at that node (Gregoire et al.1995). This is referred to as a conditional probability because the selection of one branch at a node depends on the path that has been followed and this is in turn dependent on the node from which that branch emanates. The conditional probability $\left(q_{k}\right)$ was determined using a random number generator to define the sampling path. Using randomised branch sampling, the unconditional probability $(Q)$ of selecting the $r^{\text {th }}$ section of a branch sample was determined by:

$$
Q_{r}=\prod_{k=1}^{r} q_{k}
$$

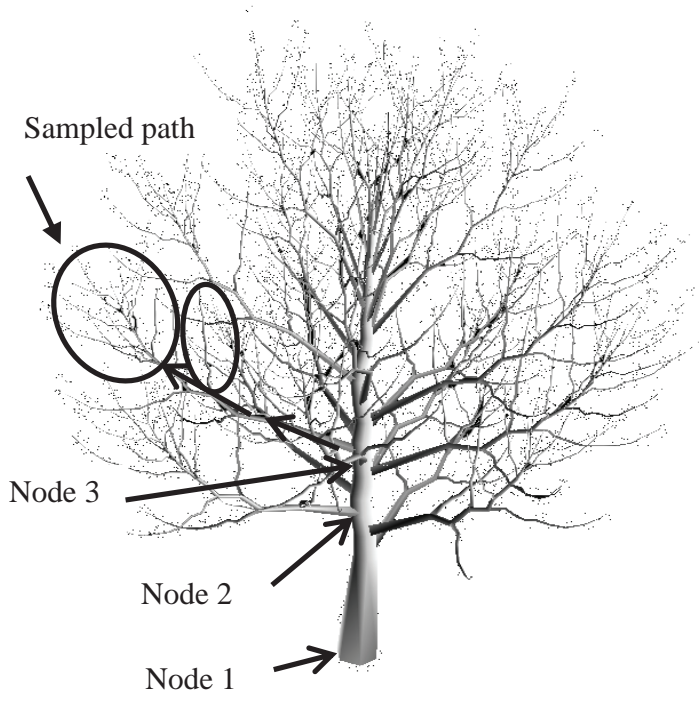

Figure 1. The Randomised branch sampling method. The sample path requires all material to be collected, including middle branches along the path. Node 1 has a probability of each selected path of $q_{1}=1$, node 2 has a probability for each selected branch of $q_{2}=1 / 4$ and node 3 has a probability of each selected branch of $q_{3}=1 / 3$. Note that the probabilities of selection assigned to the sampled branches should sum to 1 .

Método de muestreo aleatorio de ramas (RBS).El camino de muestreo requiere que todo el material sea evaluado, incluidas las ramas intermedias. El nodo 1 tiene una probabilidad de cada camino seleccionado de $\mathrm{q}_{1}=1$, el nodo 2 tiene una probabilidad para cada rama seleccionada de $\mathrm{q}_{2}=1 / 4 \mathrm{y}$ el nodo 3 tiene una probabilidad de cada rama seleccionada de $\mathrm{q}_{3}=1 / 3$. Note que las probabilidades de selección asignadas a las ramas de la muestra deben sumar 1 . 
Biomass $(\hat{b})$ amount was determined using Gregoire et al. (1995) method based on equation [2], where $b_{\mathrm{r}}$ is the amount of biomass measured on the $r^{\text {th }}$ branch and $\hat{b}$ represents the estimated amount of biomass of a tree component (i.e. branches, leaves) or the whole tree:

$$
\hat{b}=\sum \frac{b_{r}}{Q_{r}}
$$

Biomass was then calculated as the sum of the biomass of each section divided by a cumulative probability (Gregoire et al. 1995). The unbiased estimate of leaf and branch biomass was determined using equation [3]:

$$
\hat{b}=\frac{1}{m} \sum_{i=1}^{m} \hat{b_{i}}
$$

where,

$m=$ number of paths measured on a tree.

Variance was then estimated using equation [4] $m=2$ where:

$\operatorname{Var}(\hat{b})=\frac{1}{m(m-1)} \sum\left(\hat{b_{i}}-\hat{b}\right)^{2}$

Finally, each sampled path was separated into branches and leaves and oven dried at $75^{\circ} \mathrm{C}$ for 62 hours to constant weight. The total dry weight was obtained by summing the weights of all branches and leaves. The biomass and leaf area models were selected a priori before data were obtained and selection criteria are based on their use in the cited literature. For each tree species the following biomass equations [5-9] and parameters were calculated using least squares linear regressions with a $P<0.05$ :

$$
\begin{aligned}
& B_{t}=a * D B H^{b}+\varepsilon \\
& B_{t}=e^{a}+D B H^{*} * e^{b}+\varepsilon \\
& B_{t}=a+b * D B H^{2} * H_{t}+\varepsilon \\
& B_{t}=a+b * \frac{\left(\pi * D B H^{2}\right)}{4}+\varepsilon \\
& B_{t}=a * H_{t}{ }^{b}+\varepsilon
\end{aligned}
$$

where,

$B_{t}=$ crown biomass component to be estimated (the sum of leaf and branch biomass).

$a, b=$ equation variables.

$\varepsilon=$ error that has a mean of 0 and a variance of $\sigma^{2}$.

$e=$ exponent term.

$D B H=$ diameter at breast height $(1.3 \mathrm{~m})$ in centimeters.

$H=$ total height in meters.

Equations were calculated for each species using $n=10$ trees per species; similar sample size was used by Nowak (1996). Equations were based on the hypothesis that data were highly correlated with alpha $=0.05$. The selection of the appropriate model was based on the analysis of the residuals of the dependent and independent variables as well as the analysis of the goodness of fit (adjusted $\mathrm{R}^{2}$ ) and mean square error. Residuals were also tested using scatter plots, the sum of errors, goodness of fit, mean, deviation, and the sum of normalised residuals. Further tests and residual analyses can be found in Dobbs (2005).

To develop leaf area equations, the tree crown was divided into three strata. For each tree, total vertical crown height was measured and divided into 3 equal parts or an upper, middle and lower crown stratum. For each stratum, a subsample of 50 leaves was randomly collected for a total of 150 leaves per tree. A total of five trees per species were sampled both in the inner and outer portions of the crown. Leaf area samples were collected during the late summer, southern latitude months of February and March of 2005. Those dates were chosen to match the season of urban forest effects model data collection. The onesided leaf surface was calculated using a scanned image of each individual leaf (Hewlett Packard® Scanjet 2400 Scanner) with a resolution of $300 \mathrm{dpi}$ and a black/white binary scale that calculated the portion of pixels belonging to the leaf relative to the entire scanned image. Using the surface covered by 1 gram of leaf, the total leaf area was obtained by transforming these values using a total leaf weight to leaf surface relationship. Total leaf weight was obtained using the randomised branch sampling method. For each tree species, leaf area equations were developed using equations 4-8 and adjusted using least squares linear regressions with a $P<0.05$.

Verification. Available equations from literature and equations used in the urban forest effects (UFORE) model (Nowak 1996, Nowak et al. 2002, Jenkins et al. 2003) were used to verify leaf biomass and leaf area results. Distribution of tree biomass was also used to compare the results of our methods with literature for aboveground whole tree biomass allocation. Since stem biomass was needed for verification and could not be obtained using destructive sampling, the stem biomass for all sampled species was estimated using published oven dry wood densities (Anderson 2004) and measured stem volume (V) using a Smalian formula: 
$V=\frac{g_{a}+g_{b}}{2} * L$

where,

$g=$ cross sectional area of the lower $(a)$ and the upper $(b)$

section of the stem.

$L=$ length of the stem in meters.

Total whole tree above ground biomass was the sum of the estimates using the different equations for all crown components (i.e. branches and leaves) and stem biomass. Wood density values and sources from literature are presented in Dobbs (2005).

\section{RESULTS}

Branch biomass. Equations yielded better estimates for six of the 11 sampled species, where a high correlation $\left(\mathrm{R}^{2}>0.60, P<0.05\right)$ is present for three of the species and medium correlations were observed for the remainding four $\left(\mathrm{R}^{2}=[0.40-0.6], P<0.05\right)$. Results indicate unbiased estimates as exhibited by normally distributed residuals and means tending towards 0 . Scatter plots for the values obtained using randomised branch sampling and the estimates by the Dobbs (2005), i.e. this study's equations, Nowak (1996) and Jenkins et al. (2003) equations, are presented in figure 2 and table 2.

Results obtained for branch biomass equations for $\mathrm{DBH}<30 \mathrm{~cm}$ and $\mathrm{R}^{2}>0.60$ generally gave similar values as other equations from literature (figure 2; Nowak 1996, Jenkins et al. 2003). For DBH $>30 \mathrm{~cm}$ most equations

Table 2. Branch biomass equations for selected species.

Ecuaciones de biomasa de ramas de las especies seleccionadas.

\begin{tabular}{llcc}
\hline Specie & Model & $\mathrm{R}^{2}$ & MSE \\
\hline $\begin{array}{l}\text { Ailanthus } \\
\text { altissima }\end{array}$ & $\mathrm{B}=0.000007 \mathrm{DBH}^{4.422943}$ & $0.71^{*}$ & 69.17 \\
$\begin{array}{l}\text { Acer } \\
\text { negundo }\end{array}$ & $\mathrm{B}=7.130020+$ & $0.51^{*}$ & 16.24 \\
$\begin{array}{l}\text { Robinia } \\
\text { pseudoacacia }\end{array}$ & $\mathrm{B}=2.000938 \mathrm{DBH}^{2} \mathrm{H}$ & $0.54^{*}$ & 135.40 \\
$\begin{array}{l}\text { Liquidambar } \\
\text { styraciflua }\end{array}$ & $\mathrm{B}=0.000107 \mathrm{H}^{5.102728}$ & $0.45^{*}$ & 18.90 \\
$\begin{array}{l}\text { Schinus } \\
\text { molle }\end{array}$ & $\mathrm{B}=0.270671 \mathrm{H}^{1.339925}$ & $0.70^{*}$ & 24.10 \\
$\begin{array}{l}\text { Quillaja } \\
\text { saponaria }\end{array}$ & $\mathrm{B}=0.000306 \mathrm{DBH}^{3.762624}$ & $0.71^{*}$ & 24.50 \\
\hline
\end{tabular}

B: branch biomass; DBH: diameter at breast in centimetres; $\mathrm{H}$ : total height in metres; $\mathrm{R}^{2}$ : goodness of fit; MSE: mean square error. Only species and models with $\mathrm{R}^{2}>0.40$ are listed (Fischer, $*=P<0.05)$

B: biomasa de ramas; DBH: diámetro a la altura del pecho en centímetros; $\mathrm{H}$ : altura total en metros; $\mathrm{R}^{2}$ : bondad del ajuste; MSE: error cuadrático medio. Solo especies y modelos con $\mathrm{R}^{2}>0,40$ son listados (Fischer, $*=P<0,05)$. overestimated the biomass when compared to field data obtained using RBS. Some of this study equations also overestimated biomass in smaller trees showing negative and higher residuals (sum of residues $>0$ ). Overestimation of biomass for juvenile trees could be due to faster height growth rates in comparison to the diameter growth rates at early stages, affecting the diameter-height relations as seen for A. altissima, A. negundo and R. pseudoacacia. The inability to distinguish between medium and small branch size classes on certain species resulted in preventing the fit of an appropriate equation as is the case of M. boaria. Residual values were however, closer to zero; so, increasing the number of sampling paths could possibly reduce variance.

Leaf biomass. Leaf biomass equations developed are presented in table 3. For five of the species, there was a better relationship $\left(\mathrm{R}^{2}>0.60\right.$ and $\left.P<0.05\right)$ between leaf biomass and $\mathrm{DBH}$, or height, than the one obtained for branch biomass. Exceptions were A. dealbata, A. melanoxylon, P. acerifolia, P. cerasifera and M. boaria. This could be a result of the species-specific leaf size and crown characteristics. Results indicate a better relationship - as defined by higher $\mathrm{R}^{2}$ values- between leaf biomass and total height than for the branch equations. Residuals were normally distributed and exhibited average values of less than 1 kilogram. Scatter plots of leaf biomass estimates using randomised branch sampling and the Dobbs (2005), Jenkins et al. (2003) and Nowak (1996) equations are presented in figure 3 and table 3 . The adjusted equations for leaf biomass presented a lower liability for small-leaved species with smaller sized leaves and where weight-area relationship was greater (table 3 ), as can be observed for M. boaria, A. dealbata and A. melanoxylon. Jenkins et al. (2003) and this study equations yielded more reliable estimates when compared to field data. Estimates of leaf biomass for species such as $M$. boaria were not as reliable as expected probably due to species-specific crown architecture.

Leaf area. Estimated species-specific leaf area equations are presented in table 3. Results indicate that goodness of fit coefficients for leaf area are similar to branch and leaf biomass equations (tables 2 and 3). Three of the species showed a strong correlation. Residuals remained close to zero and were normally distributed. An equation for $S$. Molle could not be developed since no equation analysed in this study using this species showed any correlation between the leaf area and the DBH or total height of the tree, within a goodness of fit $<1$. Leaf area models exhibited reasonable estimates with the exception of $S$. molle. Species with $\mathrm{R}^{2}>0.40$ showed similar results when compared to Nowak (1996) equation. Developed equations seem to underestimate leaf area when compared to field data, nevertheless trends are similar (figure 4). DBH and height, however, were sufficient to estimate leaf area with the exception of S. molle. 

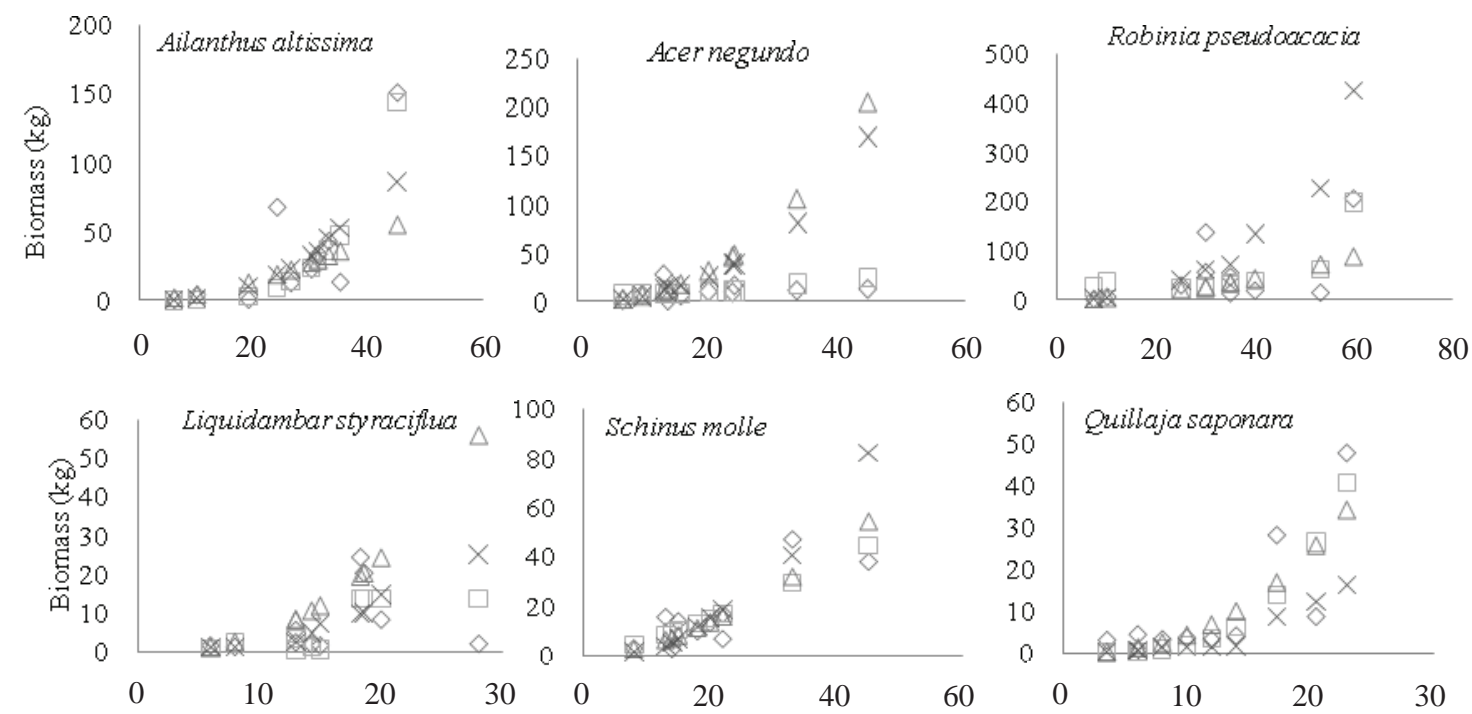

Figure 2. Scatter plots of branch biomass per tree estimates (kg) using randomized branch sampling (RBS), this study (Dobbs 2005), Nowak (Nowak 1996) and Jenkins (Jenkins et al. 2003) models. al. (2003).
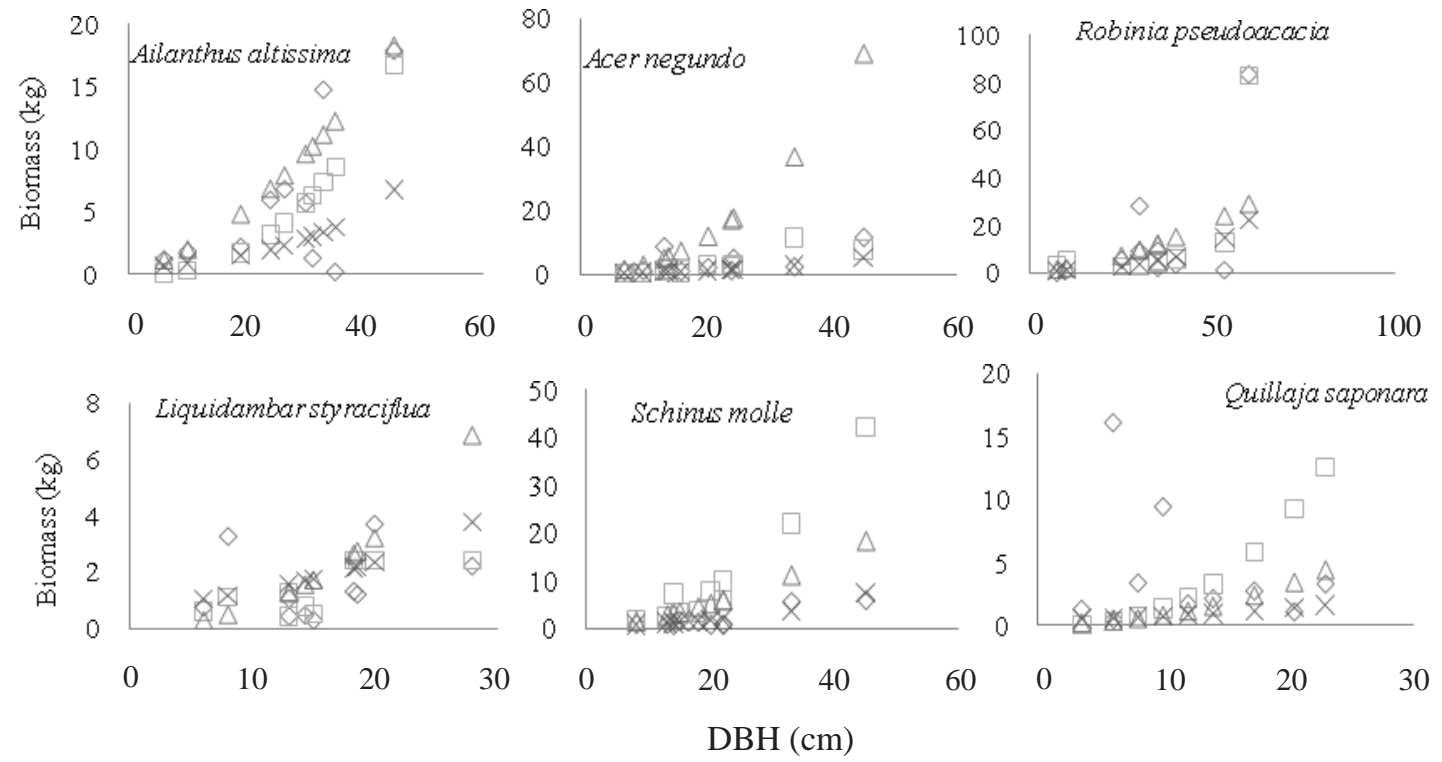

Figure 3. Scatter plots for leaf biomass per tree estimates using randomised branch sampling (RBS), this study (Dobbs 2005), Jenkins (Jenkins et al. 2003), and Nowak (Nowak 1996) equations.

Gráficos de dispersión de la biomasa de hojas estimada a través de RBS, las ecuaciones de este estudio (Dobbs 2005), de Jenkins et al. (2003) y de Nowak (1996). 
Table 3. Leaf biomass and leaf area equations for selected species.

Ecuaciones de biomasa de hojas y área foliar de las especies seleccionadas.

\begin{tabular}{|c|c|c|c|c|}
\hline Specie & Model & $\mathrm{R}^{2}$ & MSE & Weight / area ratio \\
\hline \multirow{2}{*}{ Ailanthus altissima } & $\mathrm{B}_{\text {fol }}=0.0007 \mathrm{DBH}^{2.6478}$ & $0.61 *$ & 15.89 & 0.0075 \\
\hline & $\mathrm{LA}=17.8 e^{-27.0249}+17.8 \mathrm{DBH} e^{-1.4109}$ & $0.43 *$ & 23.51 & 178.04 \\
\hline \multirow{2}{*}{ Acer negundo } & $\mathrm{B}_{\mathrm{fol}}=0.0023 \mathrm{H}^{3.6976}$ & $0.77 *$ & 3.55 & 0.0083 \\
\hline & $\mathrm{LA}=13.16 e^{-27.1760}+13.16 \mathrm{e}^{-1.6832}$ & $0.47 *$ & 8.17 & 131.66 \\
\hline \multirow{2}{*}{ Robinia pseudoacacia } & $\mathrm{B}_{\mathrm{fol}}=0.0582 \mathrm{H}^{2.6808}$ & $0.84^{*}$ & 51.57 & 0.0158 \\
\hline & $\mathrm{LA}=1.335+0.0103 \mathrm{DBH}^{2} \mathrm{H}$ & $0.74 *$ & 188.60 & 79.97 \\
\hline Liquidambar styraciflua & $\mathrm{B}_{\mathrm{fol}}=0.0164 \mathrm{H}^{2.1705}$ & $0.47 *$ & 0.83 & 0.0069 \\
\hline Schinus molle & $\mathrm{B}_{\mathrm{fol}}=0.1577+0.004 \mathrm{DBH}^{2} \mathrm{H}$ & $0.80 *$ & 0.94 & 0.0227 \\
\hline Quillaja saponaria & $\mathrm{B}_{\mathrm{fol}}=0.0028 \mathrm{DBH} 2.6821$ & $0.60 *$ & 10.63 & 0.0105 \\
\hline Prunus cerasifera & $\mathrm{LA}=24.63+0.0105 \mathrm{DBH}^{2} \mathrm{H}$ & $0.90 *$ & 6.28 & 117.17 \\
\hline Maytenus boaria & $\mathrm{LA}=6.26 e^{-0.6769}+6.26 \mathrm{DBH} \mathrm{e} \mathrm{e}^{-1.9775}$ & $0.60 *$ & 10.63 & 62.64 \\
\hline
\end{tabular}

$\mathrm{B}_{\text {fol: }}$ leaf biomass; LA: leaf area; DBH: diameter at breast height $(1.3 \mathrm{~m}$.) in centimetres; $\mathrm{H}$ : total height in metres; leaf area/weight ratio in $\mathrm{cm}^{2} / \mathrm{g}$; $\mathrm{R}^{2}$ : goodness of fit; MSE: mean square error.*Only species and models with $\mathrm{R}^{2}>0.40$ are listed (Fischer, $*=P<0.05$ ). $\mathrm{B}_{\mathrm{fol}}$ :biomasa de ramas; LA: área foliar; DBH: diámetro a la altura del pecho en centímetros; $\mathrm{H}$ : altura total en metros; leafarea/weight ratio en $\mathrm{cm}^{2} \mathrm{~g}^{-1}$; $\mathrm{R}^{2}$ : bondad del ajuste; MSE: error cuadrático medio.* Solo especies y modelos con $\mathrm{R}^{2}>0,40$ son listados (Fischer, * $=P<0,05$ ).

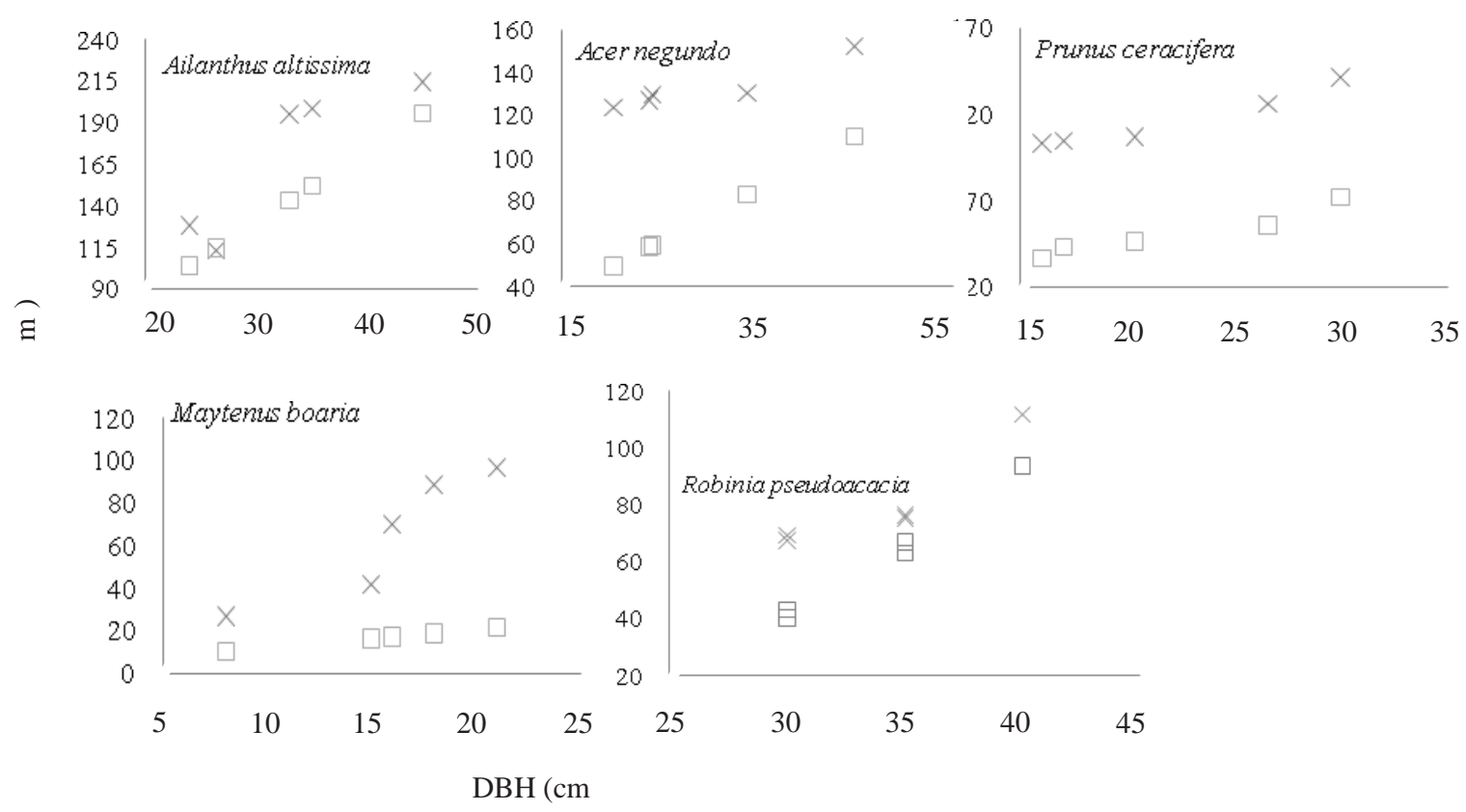

Figure 4. Scatter plots for leaf area estimates using this study (Dobbs 2005) and Nowak (1996) equations.

Gráficos de dispersión de área foliar estimada a través de las ecuaciones de este estudio (Dobbs 2005) y de Nowak (1996).

A comparison of leaf area estimates using this study (Dobbs 2005) and Nowak (1996) equations was performed and is presented in table 4. Leaf area equations from this study with an $\mathrm{R}^{2}>0.60$ generally yielded lower estimates than did Nowak equation, based on DBH and shading factors. Since shading factors are species-specific (Nowak 1996) and were only present for R. pseudoacacia, the genus or hardwood averages were used following methods outlined in Nowak et al. (2002).

Biomass allocation. Although total above-ground whole tree biomass of open grown maintained trees is less than that of forest grown trees from which biomass equations are developed (Nowak et al. 2002), table 5 provides comparable biomass proportion and allocation in the stem and crown. The proportion of total biomass allocated in 
Table 4. Comparison of leaf area estimates using this study and Nowak (1996) equations.

Comparación de estimaciones obtenidas en este estudio con las obtenidas por Nowak (1996).

\begin{tabular}{lccc}
\hline & & \multicolumn{2}{c}{$\begin{array}{c}\text { Estimated leaf area }\left(\mathrm{m}^{2}\right) \\
\text { using equation by }\end{array}$} \\
\cline { 3 - 4 } Species* & \begin{tabular}{l} 
DBH \\
\cline { 3 - 4 }
\end{tabular} & $\begin{array}{c}\text { This } \\
\text { study }\end{array}$ & $\begin{array}{c}\text { Nowak } \\
(1996)\end{array}$ \\
\hline Ailanthus altissima & 24.4 & 105.9 & 117.7 \\
Acer negundo & 17.3 & 42.3 & 46.7 \\
Prunus cerasifera & 18.3 & 44.1 & 52.3 \\
Robinia pseudoacacia & 24.6 & 47.1 & 54.6 \\
Maytenus boaria & 15.8 & 16.8 & 16.8 \\
\hline
\end{tabular}

DBH: diameter at breast height; UFORE: urban forest effects model. * Only species that have models with $\mathrm{R}^{2}>0.40$ are listed.

DBH : diámetro a la altura del pecho; UFORE: Urban Forest Effects model, modelo de efectos forestales urbanos.

* Solo especies con $\mathrm{R}^{2}>0,40$ son listadas.

Table 5. Portion of whole tree above ground biomass allocated in the crown and stem. Crown biomass was obtained using this study equations and stem biomass was estimated using a Smalian formula and published wood densities.

Proporción de biomasa en copas y fustes. La biomasa de copas fue obtenida a través de las ecuaciones obtenidas en este estudio y la biomasa fustal aplicando la fórmula de Smalian para cubicaciones.

\begin{tabular}{lrcc}
\hline \multirow{2}{*}{ Species } & \multicolumn{2}{c}{ Crown (\%) } & \multirow{2}{*}{ Stem (\%) } \\
\cline { 2 - 3 } & Leaf & Branch & \\
\hline Ailanthus altisima & 4.0 & 13.9 & 82.8 \\
Acer negundo & 7.3 & 22.9 & 69.8 \\
Acacia dealbata and & 11.9 & 28.9 & 59.2 \\
A. melanoxylon & 6.7 & 36.5 & 56.9 \\
Prunus cerasifera & 6.0 & 25.4 & 68.6 \\
Robinia pseudoacacia & 5.6 & 17.9 & 76.5 \\
Liquidambar styraciflua & 3.1 & 14.8 & 81.5 \\
Platanus acerifolia & 3.6 & 34.6 & 61.6 \\
Schinus molle & 18.2 & 33.8 & 48.1 \\
Quillaja saponaria & 6.8 & 15.5 & 77.7 \\
Maytenus boaria & 7.0 & 24.0 & 69.0 \\
Average & & & \\
\hline
\end{tabular}

the crown and stem showed similar tendencies except for $Q$. saponaria and A. dealbata and A. melanoxylon. The average distributions for whole tree biomass estimates are given by an approximate proportion of $7 \%$ for leaf biomass, $24 \%$ for branches, and $69 \%$ for stem biomass.

\section{DISCUSSION}

There are several studies that use allometric equations to estimate biomass from forests (Nowak 1994) and for urban forests (Nowak 1994, McHale et al. 2009). The accuracy in the use of allometric relations to estimate biomass has already been explored by Clarke et al. (2001) and Araujo et al. (1999). They found that these relations are highly affected by the species and stand in study. Also McHale et al. (2009) found that accuracy of the model is higly dependent on the target species. In this study, only five types of equations were selected, and the variation on the results could be showing heterogeneity among species related with their crown architecture and growth patterns. Variables such as irrigation, fertilization and location of the tree impact the tree form. Effects can be seen between species but also within species depending on species resilience. Urban tree form may vary in urban environments changing phenology, tree growth and allocation influencing allometries of urban trees.

Differences among individual tree values of the equations developed in this study and literature models selected exist. However, urban forest analyses are applied at a whole city scale making these differences not significant when evaluating urban forest functions. Improvements in allometric relationships for non USA cities could be achieved by increasing the sampling size and species for biomass purposes, or by developing a single equation from a multiple equation database as suggested by Pastor et al. (1984) and Jenkins et al. (2003).

Further development of these equations through nondestructive methods and increased randomised branch sampling sizes and path numbers should facilitate development of regional, species-specific estimates of biomass that can be used to study urban ecosystem function (Nowak et al. 2002, De la Maza et al. 2005, Escobedo et al. 2008). The equations developed for estimating leaf and branch biomass and leaf area were similar to other published equations and values obtained from urban forest structure models. Based on the results from this study, total height and DBH, which are easily measured in the field, as opposed to complex sapwood measurements or destructive whole crown weighing, can be used to estimate crown biomass in a reliable way. Other types of predictive variables, such as crown diameter or crown height, should be explored for species where the correlation coefficient was low and the mean square error was high (M. boaria, P. acerifolia, P. cerasifera, Acacia sp.). Looking for alternative independent variables that are less affected by site conditions or management regimes could explain better allometric relations, improving the predictive strength of the model. Future studies utilising this species and randomised branch sampling should increase sample size and number of paths to reduce error and compare against actual whole tree and canopy biomass weighing to validate the models discussed in this study. Also, for species that present homogeneity in crown branch size, the sampling path should be increased until the variability of data becomes steady or stable so as to obtain more reliable estimates.

In terms of the results derived from the randomised branch sampling method comparable data from literature show similar results. Values for forest-grown trees show that stem and branch biomass ranges between $72 \%$ - $90 \%$ and $9 \%$ - $22 \%$ for leaf biomass (Sternberg and Shoshany 
2001). Forest grown conifers by comparison have values averaging $54 \%$ for the stem, $10 \%$ for branches and $3 \%$ for needles (Kajumoto et al. 2006). The use of wood density values from forest trees could be giving some misleading results, however no data for urban trees existed (McHale et al. 2009).

More research is needed using destructive sampling and increased sample sizes and paths, but results seem to indicate that randomised branch sampling and equations developed in this study could be used as an alternative method and for estimating different tree crown characteristics using easily measured variables. Equation models were chosen based on literature and those commonly utilised in urban forest structure models. Even though some of them did not show a very strong relationship, they could be used as a starting point to evaluate biomass and leaf area for maintained urban, open-grown trees in Santiago. Also other types of models and independent variables could be explored to obtain more reliable estimates. Results should ideally be tested using actual biomass values obtained via destructive sampling.

The development of crown biomass and leaf area equations based on non destructive methods could be used for studies where whole tree removal is not possible as is the case in most urban areas. Crown biomass estimates and tree biomass allocations could also be used to develop wood waste supply curves that result from urban tree pruning and removal maintenance activities. Results from this study can be specifically used to improve estimates of carbon, biogenic emissions and particulate matter removal by urban trees (Nowak et al. 2002, De la Maza et al. 2005, Escobedo et al. 2008) and to assess tree shading effects on building heating and cooling effects (McPherson and Simpson 2001). These equations can also be used as a basis to quantify urban forest function for specific objectives such as determining cost-effective means of managing urban trees for the improvement of urban environmental quality. Although results were variable, this type of research serves as a basis for more precise quantification of tree physiological and environmental processes in urban central Chile and possibly other urban forests in Mediterranean climates.

\section{CONCLUSIONS}

According to results obtained from widely used models in urban forests, the estimated values for biomass and leaf area were within the expected range for the species. The use of site specific biomass and leaf area equations in urban forest effects models is not necessary.

Randomised branch sampling is an efective non-destructive method to estimate above ground biomass components in urban tress. According to the reviewed literature, the estimated values for the selected species are within expected range. Despite some degree of variation in biomass components values, specially in leaves and branches due to site-specific influence and differential management schemes of crown arquitecture, the overall distribution for above ground biomass also showed expected values. Total height and DBH, easily measured variables in the field, can be used to estimate crown biomass in a reliable way. Combining randomised branch sampling with the assessment of these two former variables can be used for an effective urban forest assessment, planning and management.

\section{ACKNOWLEGEMENTS}

Funding support was provided by Universidad de Chile, Facultad de Ciencias Forestales y Conservación de la Naturaleza, through the Project FONDEF D00I1078 and office support was provided by the USDA Forest Service, Southern Center for Urban and Interface Forestry. We would also like to thank the collaboration of Direcciones de Aseo y Ornato of Municipalidad of Lo Barnechea and La Reina.

\section{REFERENCES}

Anderson P. 2004. Part II-Species Descriptions: Schinus molle. In J Vozzo ed. Tropical Tree Seed Manual. USDA Forest Service. p. 710-712. (Agriculture Handbook 721)

Araujo TM, N Higuchi, J Jr Andrade de Carvalho. 1999. Comparison of formulae for biomass content in a tropical rain forest site in the state of Para, Brazil. Forest Ecology and Management 117(1-3): 43-52.

Chanes R. 1969. Deodendron. Árboles y arbustos de jardín en clima templado. Editorial Blume, Barcelona. 545 p.

De la Maza CL, M Rodríguez, J Hernández, MT Serra, P Gutierrez, F Escobedo, D Nowak, M Prendez, J Araya, MT Varnero. 2005. La vegetación urbana como un factor en la descontaminación. Chile Forestal 2005(13): 46-49.

Dobbs C. 2005. Construcción de modelos de biomasa y área foliar para diez especies arbóreas urbanas de la ciudad de Santiago. Tesis Ingeniero Forestal. Santiago, Chile. Facultad de Ciencias Forestales, Universidad de Chile. 85 p.

Escobedo FJ, J Wagner, DJ Nowak, CL De la Maza, M Rodríguez, DE Crane. 2008. Analyzing the cost-effectiveness of Santiago, Chile's policy of using urban forests to improve air quality. Jounal of Environmental Management 86(4): 148-157.

Gove JH, MJ Ducey, HT Valentine. 2002. Multistage point relascope and randomized branch sampling for downed coarse woody debris estimation. Forest Ecology and Management 155(1-3): 153-162.

Gregoire T, H Valentine, G Furnival. 1995. Sampling methods to estimate foliage and other characteristics of individual trees. Ecology 76(4): 1181-1194.

Hardin PJ, RR Jensen. 2007. The effect of urban leaf area on summertime urban surface kinetic temperatures: a Terre Haute case study. Urban Forestry \&.Urban Greening 6(2): 63-72.

Hoffmann A. 1999. El Arbolado Urbano en Chile. Ediciones Fundación Claudio Gay, Santiago de Chile. 255 p.

Jenkins JC, DC Chojnacky, LS, Heath, RA Birdsey. 2003. National-scale biomass estimators for United States tree species. Forest Science 49(1): 12-35.

Jessen R. 1955. Determining the fruit count on a tree by Randomized Branch Sampling. Biometrics 11(1): 99-109. 
Kajimoto T, Y Matsuura, A Osawa, A Abarmov, O Zyryanova, A Isaev, D Yefrenov, S Mori, K Takayoshi. 2006. Sizemass allometry and biomass allocation of two larch species growing on the continuous permafrost region of Siberia. Forest Ecology and Management 222(1-3): 314-325.

McHale MR, IC Burke, MA Lefsky, PJ Peper, EG McPherson. 2009. Urban forest biomass estimates: is it important to use allometric relationships developed specifically for urban trees?. Urban Ecosystems 12: 95-113.

McPherson E. 1998. Comparison of five methods for estimating leaf area index of open-grown deciduous trees. Journal of Arboriculture 24(2): 98-111.

McPherson EG, JR Simpson. 2001. Effects of California's urban forests on energy use and potential savings from large-scale tree planting. USDA Forest Service, Pacific Southwest Research Station, Center for Urban Forest Research. Davis, CA. 35 p.

Nowak DJ. 1994. Atmospheric carbon reduction by urban trees. Journal of Environmental Management 37(3): 207-217.

Nowak DJ. 1996. Estimating leaf area and leaf biomass of opengrown deciduous urban trees. Forest Science 42(4): 504-507.

Nowak DJ, DE Crane, JC Stevens, M Ibarra. 2002. Brooklyn's
Urban Forest. U.S. Department of Agriculture, Forest Service, Northeastern Research Station. 107 p. (Gen. Tech. Rep. NE-290)

McHale MR, EG McPherson, IC Burke. 2007. The potential of urban tree plantings to be cost effective in carbon credit markets. Urban Forestry \& Urban Greening 6(1): 49-60.

Pastor J, JD Aber, JM Melillo. 1984. Biomass prediction using generalized allometric regressions for some northeast species. Forest Ecology and Management 7(4): 265-274.

Peper PJ, EG McPherson. 1998. Comparison of four foliar woody biomass estimation methods applied to open-grown deciduous trees. Journal of Arboriculture 24(4): 191-200.

Rodriguez R, E Ruiz, JP Elissetche. 2005. Árboles en Chile. Editorial Universidad de Concepción. 183 p.

Sternberg M, M Shoshany. 2001. Aboveground biomass allocation and water content relationship in Mediterranean trees and shrubs in two climatological regions in Israel. Plant Ecology 157(2): 171-179.

Turner DP, SA Acker, JE Means, SL Garman. 2000. Assessing alternative allometric algorithms for estimating leaf area of Douglas-fir trees and stands. Forest Ecology and Management 126(1): 61-76.

\section{APPENDIX}

Recibido: 30.06.10

Aceptado: 31.08.11

General description of the species used in the study.

\begin{tabular}{lccccccc}
\hline \multicolumn{1}{c}{ Species } & Leaves & Bloom period & $\mathrm{H}(\mathrm{m})$ & Crown shape & Origen & Growth & Lifespan \\
\hline Ailanthus altissima & Dc & E Summer & $20-25$ & $\mathrm{~S}$ & China, Japan & Fast & Medium \\
Acer negundo & Dc & L Winter & $15-20$ & $\mathrm{~S}$ & North America & Fast & Short \\
Acacia dealbata & $\mathrm{Pr}$ & L Winter & $20-24$ & $\mathrm{~S}$ & Oceania & Fast & Short \\
Acacia melanoxylon & $\mathrm{Pr}$ & E Spring & $15-20$ & $\mathrm{C}$ & Oceania & Fast & Short \\
Prunus cerasifera & Dc & L Winter & $6-8$ & $\mathrm{~S}$ & East Europe /Asia & Fast & Short \\
Robinia pseudoacacia & Dc & Spring & $20-25$ & I/O & North America & Fast & Long \\
Liquidambar styraciflua & Dc & Spring & $20-35$ & O/C & North America & Medium & Long \\
Platanus x acerifolia & Dc & L Spring & $30-35$ & O/S & South East Europe & Fast & Long \\
Schinus molle & Pr & Winter & $20-25$ & O/I & South America & Fast & Medium \\
Quillaja saponaria & Pr & L Spring & $10-15$ & I & Chile & Medium & Medium \\
Maytenus boaria & Pr & Spring & $12-15$ & I/S & South America & Low & Medium \\
\hline
\end{tabular}

Dc: deciduous; Pr: perennial; E: early; M: mid; L: late; S: spherical; O: ovoidal; C: conic; I: irregular. Sources: Chanes (1969), Hoffmann (1998) and Rodríguez et al. (2005). 